\title{
DEVELOPING A SET MODULE WITH A GUIDED INQUIRY AND TAHFIDZUL QURAN TO IMPROVE STUDENTS' CRITICAL THINKING
}

\author{
Akhmad Syahwanul Karim ${ }^{1}$, Yus Mochamad Cholily², Mohammad Syaifuddin ${ }^{3}$ \\ ${ }^{1}$ Muhammadiyah University of Malang, Jl. Raya Tlogomas No. 246, Malang, Indonesia. \\ ask090293@gmail.com \\ ${ }^{2}$ Muhammadiyah University of Malang, Jl. Raya Tlogomas No. 246, Malang, Indonesia \\ yus@umm.ac.id \\ ${ }^{3}$ Muhammadiyah University of Malang, Jl. Raya Tlogomas No. 246, Malang, Indonesia \\ syaifuddin@umm.ac.id
}

\section{ABSTRACT}

This research aimed to develop a set module with a guided inquiry and Tahfidzul Quran (Quran memorization) to improve students' critical thinking. This research was a Research and Development (R\&D) based on the ADDIE Model with a one-group of pre-test and post-test design conducted for Year-7 students at an Islamic Boarding School in Malang, East Java. The subjects in this study were 12 students. Three aspects were present in this module development: process, quality, and effectiveness. The results of this study showed that (1) The development of the set module with a guided inquiry approach and the Tahfidzul Quran process refers to the ADDIE development model with the following steps: analysis, design, development, implementation, and evaluation; (2) The set module has a suitable quality of use as the learning module satisfying the aspects of content, presentation, language, graphics, and tahfidz; (3) The use of the set module with the guided inquiry approach and Tahfidzul Quran is effective in improving students' critical thinking. The students' responses to the learning module were positive. In conclusion, a set module developed with the guided inquiry and Tahfidzul Quran to improve students' critical thinking has fulfilled the rules of process, quality, and effectiveness.

ARTICLE INFORMATION

\section{Keywords}

Set Module

Guided Inquiry

Tahfidzul Quran

Critical Thinking
Article History

Submitted Dec 12, 2020

Revised Aug 16, 2021

Accepted Aug 25, 2021

\section{Corresponding Author}

Mohammad Syaifuddin

Universitas Muhammadiyah Malang

Jl. Raya Tlogomas 246 Malang, Jawa Timur, Indonesia

Email: syaifuddin@umm.ac.id

\section{How to Cite}

Karim, A.S., Cholily, Y.M., \& Syaifuddin, M. (2021). Developing a Set Module with A Guided Inquiry and Tahfidzul Quran to Improve Students' Critical Thinking. Kalamatika: Jurnal Pendidikan Matematika, 6(2), 111126.

https://doi.org/10.22236/KALAMATIKA.vol6no2.2021pp111-126 


\section{INTRODUCTION}

One effective, efficient, and relevant media in learning mathematics is a module (Sari, Farida, and Syazali, 2016). Teaching materials designed in module forms have more value than ordinary printed books (Diana et al., 2018a). A module promotes independent learning so that its use can be performed with or without a facilitator or teacher (Lasmiyati, 2014).

However, the current learning module has not raised awareness and students' ability to manage their thinking (Syahrir \& Susilawati, 2016). The existing module also has several shortcomings, including: (1) it does not facilitate students to express their ideas so that it makes students feel difficult to adjust with the 2013 curriculum learning method; (2) it does not facilitate students to carry out active learning activities (scientific approach); (3) the module content is difficult to understand; and (4) it does not make students feel easier to adjust (Nikmah et al., 2016).

Based on the description above, educators should develop their modules to minimize the shortage of modules. The advantages of the modules developed by educators are-that educators can adapt to the students' characteristics, including the stages of student development, the initial abilities that have been mastered, interests, family background, and so on (Khayati et al., 2016). In addition, educators can also answer or solve students' problems or difficulties in teaching that have been experienced before (Prendergast et al., 2017). A mathematics learning module that educators can develop themselves is a module that uses a guided inquiry approach (such as the modules with a guided inquiry approach developed by (Afandi, 2013) and a module integrated with the Quran (such as Sattriawan \& Sutiarso, 2017; Kenedi, Helsa, Mansur, Hendri, \& Nelliarti, 2018). "The material of teaching that simultaneously involves the related Qur'an verses can make students realize and believe in the oneness of Allah and the truth of the Qur'an as the guide of a Muslim (Sudirman \& Asriadi, 2018). The guided inquiry approach is an approach to teaching that provides direct learning experiences, involves activities, and invites students to carry out experimental activities in the form of guided discovery (Suryaningsih et al., 2016). The guided inquiry approach can improve students' conceptual understanding (Almuntasheri et al., 2016).

In addition to helping students understand the concepts, the guided inquiry approach emphasizes critical thinking processes (Afandi, 2013). The ability to think critically is one of the goals of learning mathematics (Maričića \& Špijunovićb, 2015). Critical thinking processes are part of higher order thinking skills that involve reasoning and logic to solve 
problems (Arsal, 2015; Fuad, Zubaidah, Mahanal, \& Suarsini, 2017). Therefore, students can master mathematics well (Winarso \& Dewi, 2017). The Qur'an, which consists of verses, can be used as materials for learning mathematics and the process of memorizing the Qur'an. For example, a surah consisting of several verses can be presented randomly, and students can sort them correctly. Likewise, students can also combine scrambled fragments of verses into a complete version. The process of sorting verses and combining fragments of verses requires students to think critically.

Critical thinking is also considered a combination of attitudes, knowledge, and skills (Arsal, 2015). The skills that must be possessed include listening and reading carefully, looking for and getting hidden assumptions, and exploring the consequences of a statement (Sulistyowati, 2015). Critical thinking in mathematics learning is important because students become more confident and easily adapt to math problems (Marfuah \& Subanti, 2016). Besides, the need for critical thinking skills is due to the influence of the development of science and technology, which is currently developing very rapidly (Pradana et al., 2017). Regarding critical thinking as the goal of learning mathematics, activities to develop critical thinking skills have not received full attention from teachers and students (Marfuah \& Subanti, 2016).

A module that integrates mathematics learning with the Quran is also fundamental so that the essence of mathematics learning can be understood and applied appropriately (Nasution, 2017). Mathematics learning which is carried out by embedding the concept of the Quran, can also improve students' positive attitudes and great mathematical abilities; this is because the Quran is a guide for Muslims (Kenedi et al., 2018). Knowledge of the Quran is not limited to knowledge of one thing only; but it includes comprehensive knowledge of ' $h a q^{\prime}$ ' or truth and is recognized by nature, reason, and revelation (Che et al., 2017). Research also shows that the mathematical concepts in the Quran include: algebra, geometry, sets, measurement, statistics, logic, estimation, and others (Nasution, 2017).

Many studies on module development with guided inquiry and integration with the Qur'an have been conducted. For example, the development of a guided inquiry module related to the conceptual understanding (such as Diana, Netriwati, \& Suri, 2018b) related to teacher and students' responses (such as Mardiah, Widyastuti \& Rinaldi, 2018). Besides, integrated module development using the Quran related to the conceptual understanding (such as Kurniati et al., 2018), related to teacher and students' responses (such as Kenedi et al., 2018), and related to the character of the students (such as Masduki, Khotimah, Sutarni, Toyib, \& Kholid, 2015) have also been performed. The development of a module that 
integrates both guided discovery and the Quran has also been carried out (Diana et al., $2018 \mathrm{~b}$ ). However, the development of a module with a guided inquiry approach and integrated with the Quran as the material presentation adjusted to the process of Tahfidzul Quran has not been carried out. In this study, the researcher adds an approach to presenting the material in the module using the Tahfidzul Quran process.

The module developed is targeted to students in the tahfidz class, and it is integrated with the Tahfidzul Quran program to make significant differences regarding the development process. Tahfidz education is one of the developing education practices that gain attraction in Indonesia today (Nugroho, 2016). It has been reported that hafiz students tend to perform very well in academic subjects, such as mathematics, languages, science, and religious subjects (Hassan et al., 2015).

In developing this module, validation is also done by the tahfidz teacher to see the effectiveness of the process of memorizing Quran and its analysis. Given that learning mathematics in Islamic schools or the Tahfidz class still uses teaching materials as in a general class, classroom learning is the same as there is no innovation. Therefore, it appears that mathematics learning is separated from the Tahfidz program and does not support students' memorizing power in memorizing the Quran. Hence, it is essential to develop a module in the Tahfidz class that integrates the Tahfidzul Quran program with a guided inquiry approach to make learning mathematics more meaningful. Accordingly, the objectives of developing this module are: (1) To analyze the process of developing a set module with a guided inquiry approach and the process of Tahfidzul Quran to improve critical thinking; (2) To analyze the quality of the set module with a guided inquiry approach and the process of Tahfidzul Quran in terms of content feasibility, presentation feasibility, linguistic feasibility, graphic feasibility, and eligibility for Tahfidz students; (3) To analyze the effectiveness of using the set module with a guided inquiry approach and the process of Tahfidzul Quran to improve students' critical thinking.

\section{METHOD}

This study is a Research and Development (R\&D) research using the ADDIE (Analysis, Design, Development, Implementation, and Evaluation) adopted from Ula \& Fadila (2018), as presented in Figure 1. The research design used a one-group of pre-test and post-test design. Before the treatment was given, the samples (12 students) were given a pretest. At the end of the study, the samples were also given a post-test. The research was conducted at one of the Islamic boarding schools in Malang, East Java. The research subjects 
were Year-7 students of tahfidz, particularly those who took part in the Quran memorization program.

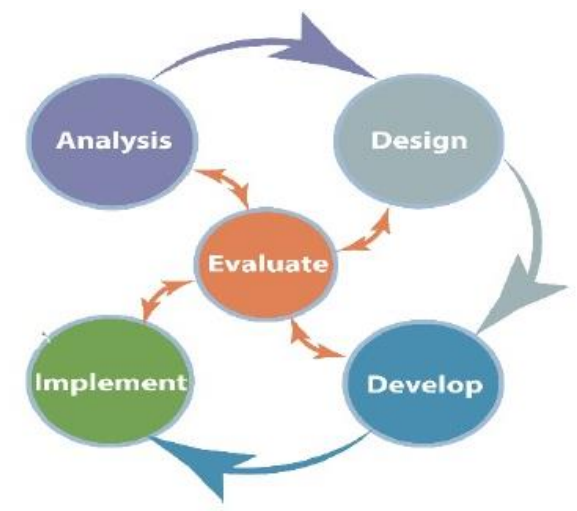

Figure 1. Module development procedure based on the ADDIE model Adopted from Ula \& Fadila (2018)

The analysis phase began see Figure 1 with a needs analysis, curriculum analysis, and analysis of the Tahfidzul Quran program. The design stages are: (1) designing the module structure, starting from the opening, the content, and the closing parts; (2) determining module specifications, of which goal is to make the module more specific and directed when it is developed; (3) compiling assessment sheet, both for the validator team and student questionnaires after participating in learning using the module. The module development stage was carried out in three steps: (1) drafting the module according to the design and specifications; (2) validating the module. Three validators validated the module. The aspects that were validated included content, presentation, linguistics, and graphics. In the aspect of content, the validation was carried out by mathematicians to assess the accuracy of the materials; also, by Tahfidz experts to assess the accuracy of the verses and suitability for students.; (3) the revision phase was carried out to improve the module based on the validator's suggestions.

Validity testing of the module used a questionnaire with an assessment of 5 scales. 1 $=$ poor $; 2=$ fair; $3=$ good $; 4=$ very good $; 5=$ excellent. The score obtained from the validator in each aspect was then calculated. The percentage of eligibility was estimated using the following formula (Diana et al., 2018a):

$$
P=\frac{\text { score }}{\text { the number of score total }} \times 100 \%
$$

Where $P=$ percentage of eligibility

Then, the percentage results obtained from the validator were categorized into very feasible, feasible, quite feasible, less feasible, and very less feasible. It was indicated when the P- 
value met the following criteria in sequence $P>84 \%, 68 \%<P \leq 84 \%, 52 \%<P \leq$ $68 \%, 36 \%<P \leq 52 \%$, and $P \leq 36 \%$, respectively.

Furthermore, the implementation stage was carried out to test the effectiveness of the module. At this stage, the implementation focused on limited trials. The limited trials were conducted in 7 meetings. The subjects consisted of 12 students of Year-7. Essay tests with four questions were given to the students in both pre-test and post-test. These tests were given to measure the students' critical thinking skills. In addition, a questionnaire containing ten statements was also given to the students to obtain student responses towards the module. The obtained data were analyzed using qualitative descriptive analysis technique and quantitative descriptive analysis technique that described the results of students' responses and the pre-test and post-test analysis. The score of the students' Critical Thinking Ability referred to Haryani (2011), the results are presented in Table 1.

Table 1. Critical Thinking Ability Scoring Table

\begin{tabular}{|c|c|c|c|}
\hline No. & $\begin{array}{l}\text { Critical thinking } \\
\text { stage }\end{array}$ & Student response & Score \\
\hline \multirow[t]{3}{*}{1.} & Interpretation & Students can mention all problems & 2 \\
\hline & & Students can mention some of the problems & 1 \\
\hline & & Students cannot mention all problems & 0 \\
\hline \multirow[t]{3}{*}{2.} & Analysis (analysis) & $\begin{array}{l}\text { Students can make a solution plan by combining all } \\
\text { relevant information to formulate problems and } \\
\text { determine the solution method }\end{array}$ & 2 \\
\hline & & $\begin{array}{l}\text { Students can make a solution plan by combining } \\
\text { some of the relevant information to formulate } \\
\text { problems and determine the solution method }\end{array}$ & 1 \\
\hline & & Students cannot make problem-solving plans & 0 \\
\hline \multirow[t]{3}{*}{3.} & Evaluation & $\begin{array}{l}\text { Students can carry out the solution plan and } \\
\text { recheck the results by applying the method and } \\
\text { checking the answers }\end{array}$ & 2 \\
\hline & & $\begin{array}{l}\text { Students can implement plans imperfectly in } \\
\text { problem-solving }\end{array}$ & 1 \\
\hline & & Students cannot carry out plans in problem-solving & 0 \\
\hline
\end{tabular}

The average score of students' critical thinking skills was categorized based on Suarsana and Mahayukti (2013) guidelines in Table 2.

Table 2. Categories of Students' Critical Thinking Ability

\begin{tabular}{cl}
\hline Score Range & Category \\
\hline$X p \geq 18,0$ & Very high \\
$18.0>X p \geq 14,0$ & High \\
$14.0>X p \geq 10,0$ & Moderate \\
$10.0>X p \geq 6,0$ & Low \\
$6.0>X p$ & Very low \\
\hline
\end{tabular}

Based on the data analysis, the module use can be said to be effective if they meet the following requirements: (1) The results of the student response percentage are at least in the good category; and (2) Students' critical thinking skills at the minimum post-test score are in the high category.

The evaluation step aimed to evaluate the results of the use of the module in a limited test. The evaluation form results were revised after examining the results of the student 
responses and the effectiveness of the developed module. The revision aimed to meet the needs or goals that were not achieved when the module was implemented.

\section{RESULTS AND DISCUSSION}

The Result of the Development Process of the Association Module with Guided Inquiry Approach and the Tahfidzul Quran Process

\section{Analysis Phase}

The needs analysis was carried out by direct observation in the Tahfidz class. Based on the observation, teaching and learning mathematics activities in the Tahfidz class were the same as activities carried out in the regular class (non-Tahfidz). Mathematics learning in the classroom did not involve any integration with the Tahfidz program or anything related to the Quran. The needs analysis was carried out by interviewing the mathematics teacher in the Tahfidz class. Based on this needs analysis, the development of a special module for students who take part in the Tahfidz program needs to supplement more interesting learning. It is also in accordance with the student characteristics. The next analysis activity was curriculum analysis. This stage was carried out by analyzing the sub materials, Core Competencies, and Basic Competencies in the set materials of grade 7 at the odd semester. Based on the analysis, there were several sub-materials in the set material, including the definition of a set, set notation, set members and non-members, zero and zero sets, universal set, set cardinality, set relations that include subsets, power sets, and two similar sets.

The last analysis stage was the analysis of the Tahfidzul Quran program. This stage was carried out by conducting direct interviews with the Tahfidz teachers. Based on the interview result, the Quran memorization for grade-7 students started from juz 30, Surah AlIkhlas. The memorization activities were carried out both inside and outside the classroom, four times a week, from Monday to Thursday to make deposits. The murojaah activities were done at the beginning of each meeting for 15 minutes together. The students' weakness so far was that most of them memorized the Quran only when they were to make deposits, but when they were asked again several weeks later, they usually halted and even forgot the verses. Based on this analysis, the module on the set material was to be developed to assist the students' murojaah process simultaneously.

Design Stage

The results of structuring the module can be seen in Figure 2 . 


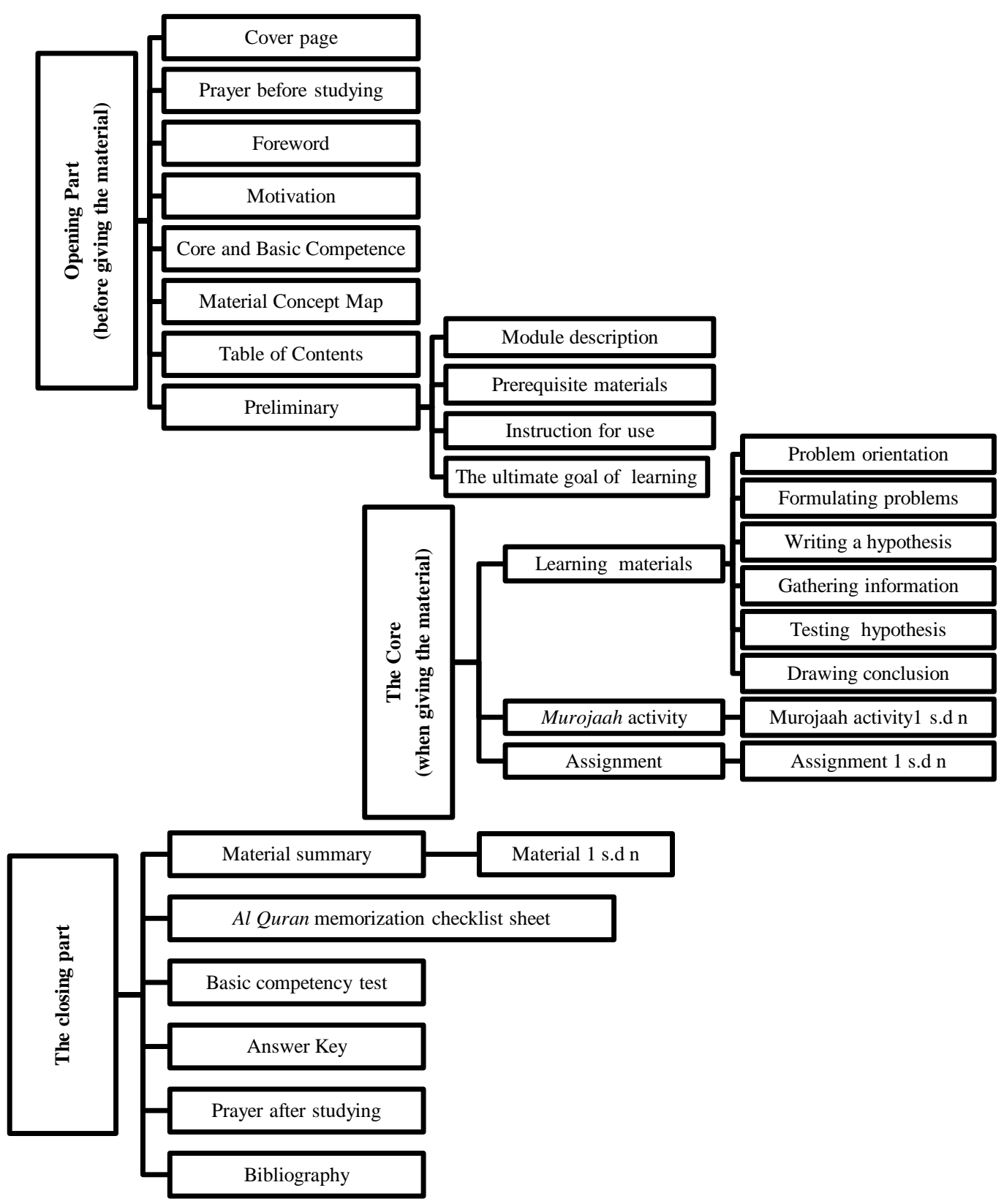

Figure 2. Module Structure Design

In this second stage, the module was designed and developed according to the previous analysis results. In this stage, the elements needed in the module, such as the preparation of a module map and a module framework, were also determined. The researchers also collected references for the content of the module and developed the instruments to assess the developed module. The instruments were prepared by taking into account the aspects of the module assessment. The instruments were a module assessment sheet and response questionnaires. Furthermore, the instruments were to be validated to obtain valid assessment instruments. 


\section{Development stage}

The module was developed referring to the components in the design, using Microsoft Office Word 2013 software and the verses of the Quran using the Quran in Microsoft Word software 32-3.0. After developing the module draft, it was validated by the validator team. The validator team consisted of a mathematics lecturer, a mathematics teacher, and a Tahfidz teacher. Figure 3 contains three images, namely 3 (a), (b), and (c), where the image/concept on the left is the initial image/concept and on the right is the revised image/concept. For example, Figure (a) represents changes to the incorrect representation of the Venn diagram, Figure (b) constitutes changes to adding facts to mathematics, and Figure (c) contains changes to the writing commands.

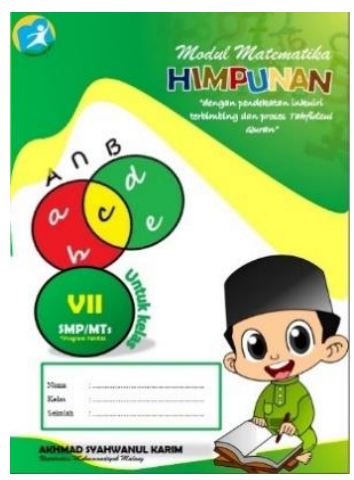

(a)
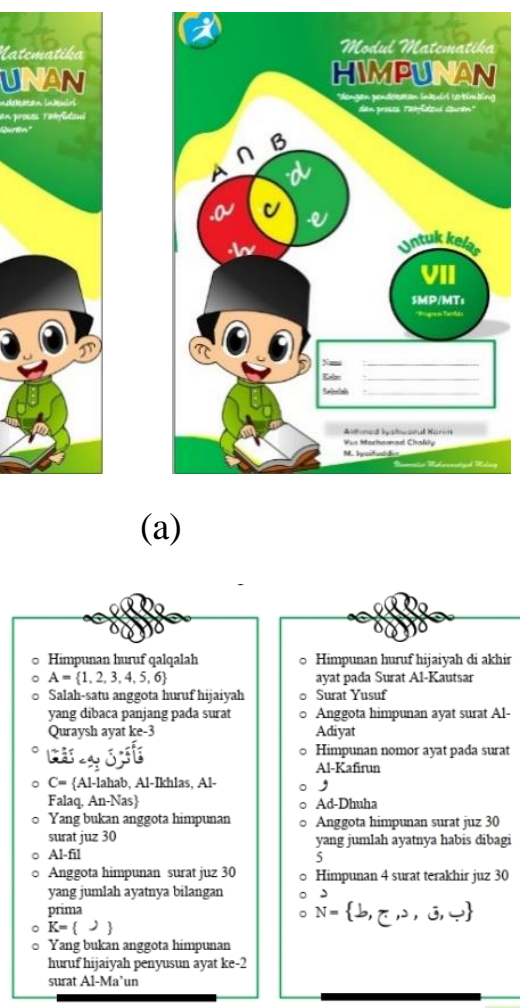
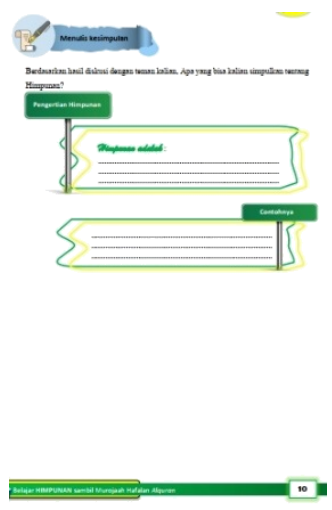

(b)
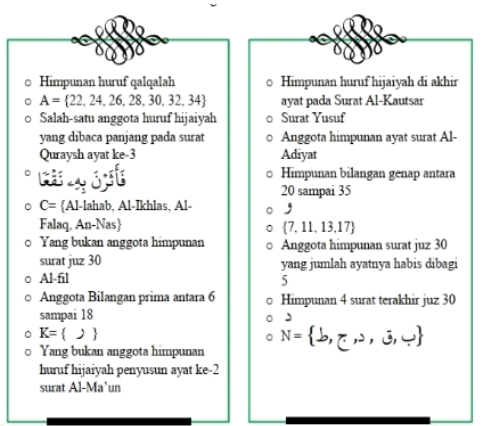

(c)

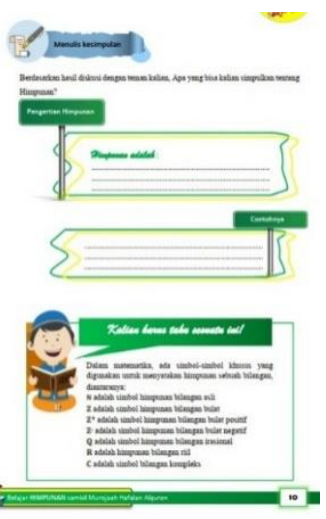

Figure 3. Some components of the module before and after the revision

Validation is carried out to determine whether the developed module is feasible or needs improvement before testing (Haryati, Hartoyo, \& Nursangaji, 2019). Further, the revision aims to perfect the module according to suggestions and input from the validators to maximize the usefulness of the module for students during the learning process (Novianti, Hartoyo, \& Nursangaji, 2021). It is also in line with the research and development conducted by (Rosnanda, Sarwanto, \& Aminah, 2017), who stated that the validation and revision 
process is critical to obtain suggestions and inputs for the module development, especially in the aspects of the material module design and language use.

\section{Implementation Stage}

The module implementation through limited trials was carried out in one week (7days-of-learning). The limited online trials generally started by distributing the module relevant to the material five minutes before the learning activity began through the WhatsApp group. The learning activity took place for $2 \times 40$ minutes, or 80 minutes. The learning activity was conducted using Google Meet with greeting, a brief explanation of the learning objectives, and student motivation. The core learning then followed it following the steps of the guided inquiry approach in the module. Next, it continued with the test to check the students' conceptual understanding and murojaah (repeat memorization) test of the Quran together. Finally, reflection and closing were carried out at the end of the class. After the learning activities were completed in 7 days, each student was given a questionnaire and post-test questions. The questionnaire contained the assessment of the learning effectiveness using the module. The result of this implementation phase was a questionnaire filled out by the students. The student questionnaire and post-test (see the results in Table 4 and Table 5) were then analyzed as the input for the module revision.

\section{Evaluation Phase}

The activity carried out at this stage was revising the final module. The revision referred to the student questionnaire and post-test results, and the module did not require revision. Thus, it can be used as a learning resource for SMP / MTs (Islamic Junior High School) students of the tahfidz program in the set material for Year-7. The results of the questionnaire showed that the students enjoyed using the module with very good student responses. Besides, the students also experienced some improvements in their critical thinking abilities as measured by their post-tests.

\section{Results of the Quality Assessment of the Association Module with Guided Inquiry Approach and the Tahfidzul Quran Process}

The results of the assessment of each aspect are shown in Table 3.

Table 3. Results of Module Validation on Each Aspect by the Validator

\begin{tabular}{lcccc}
\hline \multicolumn{1}{c}{ Aspect } & Score Obtained & Expected Score & $\begin{array}{c}\text { Percentage of } \\
\text { Eligibility (P) }\end{array}$ & Category \\
\hline Contents & & & $87 \%$ & Feasible \\
Presentation & 52 & 60 & $84 \%$ & Very Feasible \\
Language & 76 & 90 & $77 \%$ & Very Feasible \\
Graphics & 81 & 105 & $90 \%$ & Feasible \\
Tahfidz & 122 & 735 & $84 \%$ & Very Feasible \\
\hline
\end{tabular}


Based on the table above, the average aspect assessment in the module is in the feasible category. It shows that the module with a guided inquiry approach and the process of Tahfidzul Quran can be used as teaching materials for learning mathematics.

The Result of the Effectiveness Assessment of Using the Association Module with Guided Inquiry Approach and the Tahfidzul Quran Process to Improve Students' Critical

\section{Thinking}

The effectiveness of using the module can be determined through a limited trial of 12 students in the high, medium, and low categories. The data were obtained through a questionnaire and the results of the students' pre-test and post-test. The results of the student questionnaire are presented in Table 4.

Table 4. Student Response Results after Using Modules

\begin{tabular}{|c|c|}
\hline Indicator & $\begin{array}{c}\text { Total score } \\
\text { obtained }\end{array}$ \\
\hline The learning module is designed attractively & 28 \\
\hline The size and font of the learning module make it easy to read & 30 \\
\hline The language used in the module is easy to understand & 25 \\
\hline The text of the Koran provided is easy to read & 29 \\
\hline The learning module makes learning sets easier & 23 \\
\hline The learning module helps in memorizing the Koran in some of the letters chapters 30 & 30 \\
\hline The learning module increases the enthusiasm for learning mathematics & 23 \\
\hline The learning module enhances critical thinking & 24 \\
\hline The learning module makes learning mathematics more fun & 27 \\
\hline The learning module is suitable if it is used for tahfidz students & 30 \\
\hline Total number & 269 \\
\hline Percentage & $90 \%$ \\
\hline
\end{tabular}

Based on the table above, it can be identified that the student's responses to the questionnaire after being calculated showed a percentage of $90 \%$. It proves that the module has a very good response rate, and it means that students were happy and interested in the development of the module and showed a positive influence on the learning process. Furthermore, the average score of students' critical thinking skills at the pre-test and posttest can be examined in Table 5 .

Table 5. Students' Critical Thinking Ability Results

\begin{tabular}{lcc}
\hline Data size & Pre-test & Post-test \\
\hline Average Score & 13.9 & 18.9 \\
Category & Moderate & Very high \\
Maximum Score & 20 & 24 \\
Minimum Score & 7 & 12 \\
Ideal Maximum Score & 24 & 24 \\
\hline
\end{tabular}

Based on the table above, the students' post-test scores are in a very high category. Consequently, after adjusting the results of the students' questionnaires as well as the pretest and post-test with the requirements of the effectiveness of using the module, it can be argued that the use of a set module with a guided inquiry approach and the process of Tahfidzul Quran effectively improves the students' critical thinking. 


\section{CONCLUSION}

It can be concluded that the development of a set module with a guided inquiry and Tahfidzul Quran to improve students' critical thinking has been carried out according to the target (fulfilling the rules of process, the quality, and the effectiveness). It can be seen from the following aspects: The development of a set module with a guided inquiry approach and the Tahfidzul Quran process refers to the ADDIE development model with the following steps: Analysis; Design; Development; Implementation carried out by focusing on the limited trial stage; and Evaluation. The set module with the guided inquiry approach and the Tahfidzul Quran process in this research and development has fulfilled the quality of use as the learning module is based on content, presentation, language, graphics, and tahfidz. The minimum eligibility percentage was obtained by $77 \%$ with a decent category and a maximum of $90 \%$ with a very worthy category. The use of a set module with a guided inquiry approach and the Tahfidzul Quran process is declared to be effective in improving students' critical thinking. The students' responses have reached the very-good category, and the measured abilities have reached at least the high category.

\section{ACKNOWLEDGMENT}

We would like to thank the Ministry of Research and Technology, the Indonesian National Research and Innovation Agency, for providing research funding in the 2020 fiscal year, the contract number: E.5.c/077/DPPIWPNL/IIU2020. Hopefully, these research results can contribute to learning innovation in Indonesia.

\section{REFERENCES}

Afandi, A. (2013). The Effectiveness of the Guided Inquiry Approach in terms of Problem Solving Ability in Junior High School Students. Delta-Pi: Journal of Mathematics and Mathematics Education, 2(2), 21-28.

Almuntasheri, S., Gillies, R. M., \& Wright, T. (2016). The Effectiveness of a Guided Inquiry-based, Teachers 'Professional Development Program on Saudi Students' Understanding of Density. Science Education International, 27(1), 16-39.

Arsal, Z. (2015). The Effects of Microteaching on the Critical Thinking Dispositions of Preservice Teachers. Australian Journal of Teacher Education, 40(3), 140-153. 
Che, H., Rahman, A., Samian, AL, Muslim, N., \& Alam, I. (2017). Mathematical Arts of the Quran. African Journal of Basic \& Applied Sciences, 9(5), 251-258. https://doi.org/10.5829/idosi.ajbas.2017.251.258

Diana, M., Netriwati, \& Suri, FI (2018a). Islamic Nuanced Mathematics Learning Module with Inquiry Approach. Al-Jabar, 1(1), 7-13.

Diana, M., Netriwati, \& Suri, FI (2018b). Islamic Nuanced Mathematics Learning Module with Inquiry Approach. Decimal: Mathematical Journal, 1(1), 7-13.

Fuad, N. M., Zubaidah, S., Mahanal, S., \& Suarsini, E. (2017). Improving Junior High Schools' Critical Thinking Skills Based on Test Three Different Models of Learning. International Journal of Instruction, 10(1), 101-116. https://doi.org/10.12973/iji.2017.1017a

Haryani, D. (2011). Learning Mathematics with Problem Solving to Develop Students' Critical Thinking Ability. In Proceedings of the National Seminar on Research, Education and Application of Mathematics and Natural Sciences, 1980, 121-126.

Haryati, S., Hartoyo, A., \& Nursangaji, A. (2019). Pengembangan modul matematika bersumber Al-Qur'an dengan materi perbandingan di kelas VII SMP/MTs. Jurnal Pendidikan Dan Pembelajaran Khatulistiwa, 8(10), 1-11. Retrieved from https://jurnal.untan.ac.id/index.php/jpdpb/article/view/37212

Hassan, N. C., Fakhruddin, F. M., Fauzi, A., Ayub, M., \& Mutalib, L. A. (2015). Tahfiz Schools Entry Requirements and Characteristics of Tahfiz Students. IJAEDUInternational E-Journal of Advances in Education, I(3), 234-241.

Kenedi, A. K., Helsa, Y., Mansur, Hendri, S., \& Nelliarti. (2018). Development of Qur'anbased Mathematics Teaching Materials in Elementary Schools. Journal of Educational Innovation and Basic Learning, 2(1), 29-36.

Khayati, F., Sujadi, I., \& Saputro, D. R. S. (2016). Mathematics Module Development for Problem Based Learning (Problem Based Learning) on the Main Material of Straight Line Equations for Class VIII Junior High Schools. Journal of Learning 
Mathematics,

$4(7)$,

$608-621$.

http://jurnal.fkip.uns.ac.id/index.php/s2math/article/view/9167

Kurniati, A., \& Nufus, H. (2018). Pengembangan Buku Keajaiban Angka Dalam Alqur'an Dilengkapi Media Kartu Angka. MaPan, 6(2), 173-186. https://doi.org/10.24252/mapan.2018v6n2a4

Lasmiyati, I. H. (2014). Development of Learning Modules to Improve Concepts Understanding and Interests of Junior High Schools Developing a Module to Improve Concept Understanding and Interest of Students of SMP. Pythagoras: Mathematics $\quad$ Education, $\quad 9(2), \quad 161-174$. https://journal.uny.ac.id/index.php/pythagoras/article/viewFile/9077/pdf

Mardiah, S., Widyastuti, R., \& Rinaldi, A. (2018). Pengembangan Modul Pembelajaran Matematika Berbasis Etnomatematika Menggunakan Metode Inkuiri. Desimal: Jurnal Matematika, 1(2), 119. https://doi.org/10.24042/djm.v1i2.2228

Marfuah, I., \& Subanti, S. (2016). Students' Critical Thinking Process in Two Variables Viewed from the Learning Style of Class IX B SMP Negeri 2 Surakarta. Journal of Electronic Mathematics Learning, 4(7), 622-632.

Maričića, S., \& Špijunovićb, K. (2015). Developing Critical Thinking in Elementary Mathematics Education through a Suitable Selection of Content and Overall Student Performance. Procedia - Social and Behavioral Sciences, 180(November 2014), 653659. https://doi.org/10.1016/j.sbspro.2015.02.174

Masduki, Khotimah, R. P., Sutarni, S., Toyib, M., \& Kholid, M. N. (2015). Integrating Islamic Values in Mathematics Learning: a Strategy of Developing Student's Character. University Research Colloquium, 3(2), 216-232.

Nasution, A. F. (2017). Implementation of Mathematical Concepts in the Koran in the Madrasah Curriculum. EduTech Journal, 3(1), 1-11.

Nikmah, Sajidan, \& Karyanto, P. (2016). Development of the Biology Module Inquiry Based on Interactive Demonstration to Empower Learning Outcomes of Class XII IA 
Students on Biotechnology Material in SMA Negeri 1 Magelang. Journal of Inquiry, 5(3), 104-112.

Novianti, Hartoyo, A., \& Nursangaji, A. (2021). Pengembangan Bahan Ajar Bersumber AlQur' An Berbentuk Modul Pada Materi Fungsi Kelas X. Journal of Aunthentic Research on Mathematics Education (JARME), 3(2), 217-232.

Nugroho, B. T. A. (2016). The Effect of the Tahfidzul Qur 'An Learning Method on Learning Achievement of Tahfidzul Qur' An. Attarbiyah. Journal of Islamic Culture and Education, I(2), 211-242. https://doi.org/10.18326/attarbiyah.v1i2.

Pradana, S. D. S., Parno, \& Handayanto, S. K. (2017). Development of Critical Thinking Ability Tests in Optical Geometry Material for Physics Students Shan. Journal of Educational Research and Evaluation, 21(1), 51-64.

Prendergast, M., Spassiani, N. A., \& Roche, J. (2017). Developing a Mathematics Module for Students with Intellectual Disability in Higher Education. International Journal of Higher Education, 6(3). https://doi.org/10.5430/ijhe.v6n3p169

Puti, S., \& Jumadi. (2015). Development of Guided Inquiry-Based Junior Science Module Development to Improve Process Skills and Attitudes. Journal of Mathematics and Science Education, 3(1), 79-90.

Rosnanda, D., Sarwanto, S., \& Aminah, N. S. (2017). Pengembangan Modul Pembelajaran Berbasis Masalah Pada Materi Litosfer Untuk Meningkatkan Keterampilan Berpikir Kritis Siswa Smp. INKUIRI: Jurnal Pendidikan IPA, 6(3), 141-152. https://doi.org/10.20961/inkuiri.v6i3.17866

Sari, FK, Farida, \& Syazali, M. (2016). Development of Geogebra Assisted Learning Media (Modules) with Derivative Subjects. Al-Jabar: Journal of Mathematics Education, $7(2), 135-152$.

Sattriawan, A., \& Sutiarso, S. (2017). Developing Religious Character through Mathematics Learning. In Proceedings of the National Seminar on Mathematics and Mathematics Education 2017, 191-196. 
Suarsana, I. M. \& Mahayukti, G.A. (2013). Pengembangan E-Modul Berorientasi Pemecahan Masalah Untuk Meningkatkan Keterampilan Berpikir Kritis Mahasiswa. JPI (Jurnal Pendidikan Indonesia), 2(2), 264-275.

Sudirman, S., \& Asriadi, M. (2018). Developing fundamental physics module integrated with Al-Quran in Physics Education Department, Faculty of Education and Teacher Training, Alauddin State Islamic University of Makassar. In Proceeding of the Seminar Nasional Fisika (SNF) 2018, 55-65.

Sulistyowati, R. (2015). Improve students' critical thinking skills in salesmanship courses through assignment methods. In Proceedings of the National Seminar, 9 May 2015, 219-225.

Suryaningsih, N. M. A., Cahaya, I. M. E., \& Poerwati, C. E. (2016). Implementation of Game-Based Guided Inquiry Learning in Improving Early Childhood Creativity. Indonesian Journal of Education, 5(2), 921-929.

Syahrir, \& Susilawati. (2016). Development of Mathematics Learning Module for Junior High School Students. Mandala Education Scientific Journal, 1(2), 162-171.

Ula, I. R. \& Fadila, A. (2018). E-Module Development Based on Learning Content Development System Subjects on Junior High School Number Patterns. Decimal: Mathematical Journal, 1(2), 201-207.

Winarso, W., \& Dewi, W. Y. (2017). Critical Thinking of Middle School Students in Solving Geometry Problems in terms of Cognitive Style of Visualizer and Verbalizer. Journal of Mathematical Tadris, 10(2), 117-133. https://doi.org/10.20414/betajtm.v10i2.109 